\title{
Ecological variation within traditional diatom morphospecies: diversity of Frustulia rhomboides sensu lato (Bacillariophyceae) in European freshwater habitats
}

\author{
Jana Veselí*, Pavla Urbánková, Kateřina Černá and Jiří Neustupa \\ Department of Botany, Faculty of Science, Charles University in Prague. Benátská 2, CZ-12801 Prague, Czech Republic
}

\begin{abstract}
Veselá J., Urbánková P., Černá K. And Neustupa J. 2012. Ecological variation within traditional diatom morphospecies: diversity of Frustulia rhomboides sensu lato (Bacillariophyceae) in European freshwater habitats. Phycologia 51: 552-561. DOI: 10.2216/11-101.1
\end{abstract}

\begin{abstract}
More than 300 strains of Frustulia rhomboides sensu lato were isolated from populations across Europe to estimate its molecular diversity and geographic distribution in oligotrophic freshwater habitats. Phylogenetic analyses, based on partial large subunit (LSU) rDNA sequences, revealed six lineages that did not fully correspond with the separation of $F$. rhomboides into traditional varieties. Although four closely related lineages showed substantial overlaps in morphology, the characteristic morphological features could be determined using morphometric techniques. The phylogenetic lineages of $F$. rhomboides showed different patterns of distribution among regions. Sequence frequencies within samples from different habitats indicated that distribution of the common lineages most likely reflected their different ecological preferences rather than dispersal constraints.
\end{abstract}

KeY Words: Biogeography, Cryptic species, Diatoms, Frustulia rhomboides, Geometric morphometrics, LSU rDNA

\section{INTRODUCTION}

A multidisciplinary approach to the discovery and delimitation of protist species (e.g. Behnke et al. 2004; Mann et al. 2004; Lowe et al. 2005a; Pröschold \& Leliaert 2007; Weisse et al. 2008) has renewed a debate regarding species concepts (Mann 1999, 2010; de Queiroz 2005, 2007; Fenchel \& Finlay 2006). Molecular genetic methods, morphometric techniques, breeding experiments, and cultivation under controlled conditions have revealed hidden diversity within traditional morphologically defined species. However, conflicting evidence regarding species boundaries indicated that rates of morphological and molecular evolution may be decoupled (Philippe et al. 1994; Alverson 2008), and reproductively compatible strains may be isolated by spatial or temporal separation (Behnke et al. 2004; Casteleyn et al. 2008). Furthermore, the molecular markers may not reflect the ecophysiological differentiations of the strains (Fenchel 2005; Lowe et al. 2005b; Weisse 2008), and the measured theoretical niche may be broader than the realized niche (Boenigk et al. 2007; Vanelslander et al. 2009). These phenomena suggest that species discovery and description should be based upon a combination of results acquired by different approaches instead of relying on any single approach (de Quieroz 2007; Mann 2010).

Frustulia rhomboides (Ehrenberg) De Toni sensu Krammer \& Lange-Bertalot (1986) contains five intraspecific taxa in Europe: F. rhomboides var. rhomboides, F. rhomboides var. saxonica (Rabenhorst) De Toni, F. rhomboides var. crassinervia (Brebisson) Ross, F. rhomboides var. amphipleuroides (Grunow) De Toni, and F. rhomboides var. viridula (Brebisson) Cleve. Recent nomenclatural changes raised these morphotypes to the species level, Frustulia krammeri

*Corresponding author (vesela6@natur.cuni.cz).
Lange-Bertalot \& Metzeltin, Frustulia saxonica Rabenhorst, Frustulia crassinervia (Brebisson) Lange-Bertalot \& Krammer, Frustulia amphipleuroides (Grunow) Cleve-Euler, and Frustulia erifuga Lange-Bertalot \& Krammer (for details, see Lange-Bertalot \& Metzeltin 1996; Lange-Bertalot \& Jahn 2000; Lange-Bertalot 2001). However, these taxonomic changes and the greater number of micrographs of natural populations from diverse geographic areas have instead complicated the distinctions between $F$. krammeri ( $F$. rhomboides), $F$. saxonica, and $F$. crassinervia (Siver \& Baskette 2004). The most commonly reported taxa worldwide are the morphotypes $F$. saxonica and $F$. crassinervia (Lange-Bertalot 2001; Siver \& Baskette 2004; Beier \& Lange-Bertalot 2007); both are characteristic members of phytobenthos in acid, peaty waters (such as Sphagnum bogs), and many ephemeral habitats (Krammer \& LangeBertalot 1986; Round et al. 1990; Wehr \& Sheath 2002). In the present study, diverse European regions and habitats were sampled to obtain monoclonal cultures in order to (1) analyse the phylogenetic structure, (2) assess the qualitative and quantitative morphological variation of the lineages, and (3) describe the distribution patterns of the lineages.

\section{MATERIAL AND METHODS}

Between October 2007 and June 2010, 62 benthic samples were taken from diverse freshwater oligotrophic biotopes (ombrotrophic peat bogs, minerotrophic mires, Sphagnum dominated littoral of lakes, and ephemeral habitats) in nine European regions. Localities in the Czech Republic (CZ), western Ireland (IE), and south-western France (FR) were studied in detail; samples from other localities were incidentally collected, i.e. the Azores Islands (PT), Germany (DE), the Netherlands (NL), Slovakia (SK), Slovenia 
(SI), and Sweden (SE) (for details, see Table S1). The epipelic communities were collected from the surface of the sediment by means of a collection tube, and the epiphytic samples were obtained by squeezing the bryophytes. The samples from sites with both microhabitats were represented by a mixture of epiphytic and epipelic communities. Conductivity and $\mathrm{pH}$ values were measured in the field using a combined $\mathrm{pH} /$ conductometer WTW 340i (Wissenschaftlich-Technische Werkstätten GmbH, Weilheim, Germany). Climatic conditions were reconstructed from the temperature values measured by the meteorological stations in closest proximity to the locality (http://www.wunderground.com; for details, see Table S2). Temperature values were corrected according to the altitude of the sampling locality $\left(-0.65^{\circ} \mathrm{C}\right.$ per $100 \mathrm{~m}$ increase in altitude). Monoclonal cultures were isolated from natural samples using a mouth-pipetting technique, following Edgar \& Theriot (2004). A randomly chosen cell was transferred (using sterile Pasteur pipettes with an ultrathin tip) through a series of drops of sterile medium in order to minimize the risk of potential contamination. In total, 378 isolates were successfully grown in oligotrophic liquid medium (recipe from the Culture Collection of Algae of Charles University of Prague, http://botany.natur.cuni.cz/algo/caup-media.html). The medium was enriched with sodium metasilicate $(8 \mathrm{ml} 0.05 \mathrm{M}$ $\mathrm{Na}_{2} \mathrm{SiO}_{3} \cdot 9 \mathrm{H}_{2} \mathrm{O} 1^{-1}$ medium). The final $\mathrm{pH}$ was adjusted using $\mathrm{NaOH}$ and $\mathrm{HCl}$ to the $\mathrm{pH}$ value measured at a particular locality. Cultures were maintained at $18^{\circ} \mathrm{C}$ using continuous illumination $\left(5-15 \mu \mathrm{mol}\right.$ photons $\mathrm{m}^{-2} \mathrm{~s}^{-1}$ ) from a white fluorescent tube. Cultures were inoculated from 96 well tissue-culture plates into glass Petri dishes $(90 \mathrm{~mm}$ diameter) one month after isolation; cells were harvested with a sterile pipette over the next 2-3 months. Frozen cultures and voucher material were deposited in the Laboratory of Phycology, Department of Botany, Charles University in Prague, Czech Republic.

For the amplification of the D1/D2 region of the nuclearencoded large subunit (LSU) rDNA, a modified "singlecell" polymerase chain reaction (PCR) approach was followed (for details see Poulíčková et al. 2010). With published diatom sequences (GenBank database) and early partial sequences amplified with nonspecific D1R/D2C primers (Yeung et al. 1996), the final specific primers were designed as follows: forward LSU-80DF (5'-AGTAAGGGCGACTGAA-3') or LSU-DF1 (5'-AGTAAGGGCGACTGAAG-3') and reverse LSU-740DR (5'-ACCCTATTCAGGCATAGTT-3') or LSU-710DR (5'-AGCCTCCACCAGAGTTTCCCCTGGC-3'). In all cases the AmpliTaq Gold DNA Polymerase (Applied Biosystems, Carlsbad, California, USA) was used. PCR conditions were $94^{\circ} \mathrm{C}$ for $10 \mathrm{~min} ; 35$ cycles at $94^{\circ} \mathrm{C}$ for $1 \mathrm{~min}, 51^{\circ} \mathrm{C}$ for $1 \mathrm{~min}, 72^{\circ} \mathrm{C}$ for $1 \mathrm{~min}$; and a final extension at $72^{\circ} \mathrm{C}$ for $10 \mathrm{~min}$. PCR products were purified either by a JetQuick PCR Product Purification Kit (Genomed, Löhne, Germany) or a Qia Mini Elute Gel Extraction Kit (Qiagen Inc., Valencia, CA, USA) and then sequenced by Macrogen Inc. (Seoul, South Korea). Sequences were obtained from 353 Frustulia rhomboides strains. Raw sequences were edited in SeqAssem (SequentiX, Klein Raden, Germany), and ambiguous positions (intraclonal sequence variation) were manually screened, following Beszteri et al. (2005). Ambiguities that could not be resolved were retained in the alignment. Since some sequences were of poor quality, a set of 339 complete sequences was used in the recognition of identical sequences (MEGA ver. 3.1; Kumar et al. 2008). The alignment of 25 unique sequences was done manually using RNA secondary structure that was constructed in 4Sale (Seibel et al. 2006, 2008) according to the published secondary structures (Sato et al. 2008; Poulíčková et al. 2010). After deletion of the 5' and $3^{\prime}$ ends and after exclusion of the variable part in the ending loop of stem $\mathrm{C} 1$, the final length was $533 \mathrm{bp} ; 18$ variable characters were parsimony-uninformative, and 42 characters were parsimony-informative. The sequence alignment is available from the authors upon request. Unique sequences were deposited in GenBank under the accession numbers HE601709-HE601733 (Table 1).

Phylogenetic analyses were performed with Bayesian inference (BI) methods using MrBayes ver. 3.1.2 (Huelsenbeck \& Ronquist 2001); maximum likelihood (ML) using Garli ver. 0.951 (Zwickl 2006); and maximum parsimony (MP) using PAUP ver. 4.0b10 (Swofford 2001). The general-time-reversible model with invariable sites and gamma distribution was identified by PAUP/MrModeltest ver. 2.3 (Nylander 2004) as the most appropriate model of sequence evolution. The unrooted phylogenetic tree was inferred with BI. Two parallel Markov chain Monte Carlo runs were carried out for three million generations, each with one cold and three heated chains. Trees and parameters were sampled every 100 generations, and a tree burn-in value was set to 100. ML and MP analyses for bootstrap supports of phylogenetic lineages were set according to Škaloud \& Peksa (2010).

Strains used in the morphometric analyses were selected with respect to their genetic and geographic distance to enable the evaluation and comparison of both intragroup and intergroup variation (Table 1). Frustules were cleaned by incineration (Battarbee et al. 2001) and mounted in Naphrax (Brunel Microscopes Ltd, Wiltshire, UK). Images of the valves, focused on their outline, were photographed with an Olympus BX51 (UPlan FLN 100x/1.30 oil objective, differential interference contrast imaging), using Olympus Z5060 digital microphotographic equipment (Tokyo, Japan). Ultrastructural characters (striae and areolae density, shape of helictoglossa, and raphe endings) for 11 strains were observed using a scanning electron microscope SEM JEOL 6380LV (Tokyo, Japan). Frustules of strains examined by electron microscopy were cleaned using the hydrogen peroxide-potassium permanganate method (Krammer \& Lange-Bertalot 1986) and coated with an ultrathin layer of gold. All lineages of Frustulia rhomboides (2-14 strains from each lineage) were also characterized by conventional morphometric measurements (length, breadth, and length/breadth). Valve outlines of the most closely related lineages with a similar morphology (33 strains) were examined by geometric morphometrics. In this landmarkbased geometric morphometric study, 30 valves from each strain (990 valves) were analysed using thin-plate spline (TPS) software (Rohlf 2010). The shape of the cells was represented by configurations of 46 landmarks (digitized in TpsDig ver. 1.4); one fixed landmark was situated on the apex of the cell, and 45 sliding landmarks (= semilandmarks sensu Bookstein 1997) were regularly spaced 
Table 1. Culture strains representing unique sequences used for phylogenetic and morphological studies.

\begin{tabular}{|c|c|c|c|c|c|}
\hline Strain & Lineage $^{1}$ & Sample $^{2}$ & Region & $\begin{array}{l}\text { GenBank } \\
\text { accession no. }\end{array}$ & Morphometric analyses \\
\hline F203 & I & S20 & $\mathrm{CZ}$ & HE601709 & $\mathrm{F} 197^{3}-\mathrm{S} 18$ \\
\hline F278 & I & S52 & IE & HE601710 & $\mathrm{F} 309^{3}-\mathrm{S} 39 ; \mathrm{F} 367^{4}-\mathrm{S} 54$ \\
\hline F285 & II & S41 & IE & HE601711 & $\mathrm{F} 378^{4,6} \mathrm{~F} 381^{3,6}-\mathrm{S} 41$ \\
\hline $\mathrm{F} 237^{4,5}$ & III & S35 & FR & HE601712 & $\mathrm{F} 331^{3,5,6}-\mathrm{S} 49 ; \mathrm{F} 350^{3,5,6}-\mathrm{S} 51$ \\
\hline $\mathrm{F} 28^{4,5}$ & IV & S58 & SE & HE601713 & $\mathrm{F} 25^{3,5}-\mathrm{S} 15$ \\
\hline$F 259^{4,5}$ & IV & $\mathrm{S} 34$ & FR & HE601714 & $\mathrm{F} 153^{3,5} \mathrm{~F} 177^{3,5}-\mathrm{S} 57 ; \mathrm{F} 265^{3,5}-\mathrm{S} 34$ \\
\hline F52 & V & S43 & IE & HE601715 & $\mathrm{F} 215^{3,5}-\mathrm{S} 24$ \\
\hline F55 & $\mathrm{V}$ & S46 & IE & HE601716 & - \\
\hline F228 & $\mathrm{V}$ & S37 & FR & HE601717 & $\mathrm{F} 260^{4,5,6} \mathrm{~F} 263^{4,5}-\mathrm{S} 34 ; \mathrm{F} 274^{3,5} \mathrm{~F} 292^{3,5}-\mathrm{S} 38$ \\
\hline F234 & $\mathrm{V}$ & S37 & FR & HE601718 & - \\
\hline F238 & $\mathrm{V}$ & S35 & FR & HE601719 & - \\
\hline F272 & $\mathrm{V}$ & $\mathrm{S} 38$ & FR & HE601720 & $\mathrm{F} 50^{3,5}-\mathrm{S} 43 ; \mathrm{F} 300^{3,5} \mathrm{~F} 301^{3,5}-\mathrm{S} 53 ; \mathrm{F} 329^{4,5} \mathrm{~F} 332^{3,5}-\mathrm{S} 49$ \\
\hline F282 & $\mathrm{V}$ & S52 & IE & HE601721 & $\mathrm{F} 77^{3,5}-\mathrm{S} 33 ; \mathrm{F} 355^{3,5}-\mathrm{S} 40$ \\
\hline F283 & $\mathrm{V}$ & S52 & IE & HE601722 & - \\
\hline F293 & $\mathrm{V}$ & $\mathrm{S} 53$ & IE & HE601723 & - \\
\hline F375 & V & $\mathrm{S} 52$ & IE & HE601724 & - \\
\hline F6 & VI & S26 & $\mathrm{CZ}$ & HE601725 & - \\
\hline $\mathrm{F} 22^{5}$ & VI & S60 & SI & HE601726 & - \\
\hline F33 & VI & S60 & SI & HE601727 & $\mathrm{F} 113^{3,5} \mathrm{~F} 123^{3,5}-\mathrm{S} 56 ; \mathrm{F} 118^{3,5} \mathrm{~F} 144^{3,5}-\mathrm{S} 57$ \\
\hline F59 & VI & S5 & $\mathrm{CZ}$ & HE601728 & - \\
\hline F69 & VI & S7 & $\mathrm{CZ}$ & HE601729 & - \\
\hline F106 & VI & $\mathrm{S} 21$ & $\mathrm{CZ}$ & HE601730 & - \\
\hline F151 & VI & S56 & PT & HE601731 & - \\
\hline $\mathrm{F} 275^{4,5}$ & VI & S 38 & FR & HE601732 & $\mathrm{F} 288^{4,5}-\mathrm{S} 38$ \\
\hline F395 & VI & $\mathrm{S} 45$ & IE & HE601733 & $\begin{array}{l}\mathrm{F} 10^{3}-\mathrm{S} 27 ; \mathrm{F} 65^{4,5}-\mathrm{S} 6 ; \mathrm{F} 76^{3}-\mathrm{S} 2 ; \mathrm{F} 93^{3,5}-\mathrm{S} 31 ; \mathrm{F} 129^{3}-\mathrm{S} 28 ; \\
\text { F165 }\end{array}$ \\
\hline
\end{tabular}

\footnotetext{
${ }^{1}$ Roman numbers I-VI, unnamed lineages (see text).

${ }^{2}$ Sample sites, see Table S1.

3 Conventional morphometric measurements.

${ }^{4}$ Conventional morphometry and scanning electron microscopy.

${ }_{6}^{5}$ Geometric morphometrics.

${ }^{6}$ Strains with partial sequence.
}

along the outline. Shape coordinates were computed by Procrustes superposition of landmarks (TpsRelw ver. 1.46). The allometric component of shape variation was removed by multivariate regression of shape coordinates on centroid/ geometric size using $\mathrm{R}$ ver. 2.8.1 ( $\mathrm{R}$ Development Core Team 2008). The resulting data set, the regression residuals, was used in the subsequent analyses, which assessed both the qualitative and quantitative nonallometric shape variation of the strains. The mean valve shapes of the lineages or strains were visualised by the thin plate spline method as deformations from the overall mean configuration of landmarks of the entire dataset (TpsSplin ver. 1.20). The principal component analysis (PCA) diagram was performed to show the ordination of cells and centroids of strains according to their morphological similarity. The differences between the morphology of the phylogenetic lineages were tested by nonparametric pairwise comparisons with a Bonferroni correction; the univariate Mann-Whitney test and multivariate analysis of variance (NPMANOVA) based on the Mahalanobis distances were calculated. The canonical variates analysis (CVA) quantified the morphological distinctness between phylogenetic lineages, using Mahalanobis distances. Univariate statistics, PCA, NPMANOVA, and CVA were performed in PAST ver. 2.08 (Hammer et al. 2001). The ordination diagram was made in SigmaPlot ver. 9 (Systat Software Inc., San Jose, CA, USA).

Sequence frequencies of the lineages at the sampling sites were calculated from the whole dataset of 353 sequences; both complete and partial sequences were used (not shortened as in alignment). The frequencies of the most closely related and common lineages (325 sequences) were visualized using pie charts (SigmaPlot ver. 9). Correlations between different distance matrices of sampling sites, which were represented by at least four sequences, were tested using a partial Mantel test within zt-software (Bonnet \& Van de Peer 2002). The matrix of sequence frequencies of lineages was calculated using a Bray-Curtis similarity index. The biotope matrix was qualitatively coded as to biotope type either as match (1), or mismatch (0). The matrices of environmental factors were obtained from standardized Euclidean distances of the climatic factors (altitude, temperature characteristics) as well as measured water parameters ( $\mathrm{pH}$, conductivity). The geographic distance matrix was calculated from global positioning system coordinates of localities. The primary data for the matrices' calculations are shown in Table S1. Differences between environmental variables at sampling sites that were dominated by one of the common lineages were tested by a series of permutation $t$ tests in PAST ver. 2.08. Sites represented by a single sequence were omitted from these calculations.

\section{RESULTS}

The vast majority of partial LSU rDNA sequences showed intraclonal polymorphism at 1-5 sites, in which the positions varied among the lineages. Since in many cases 


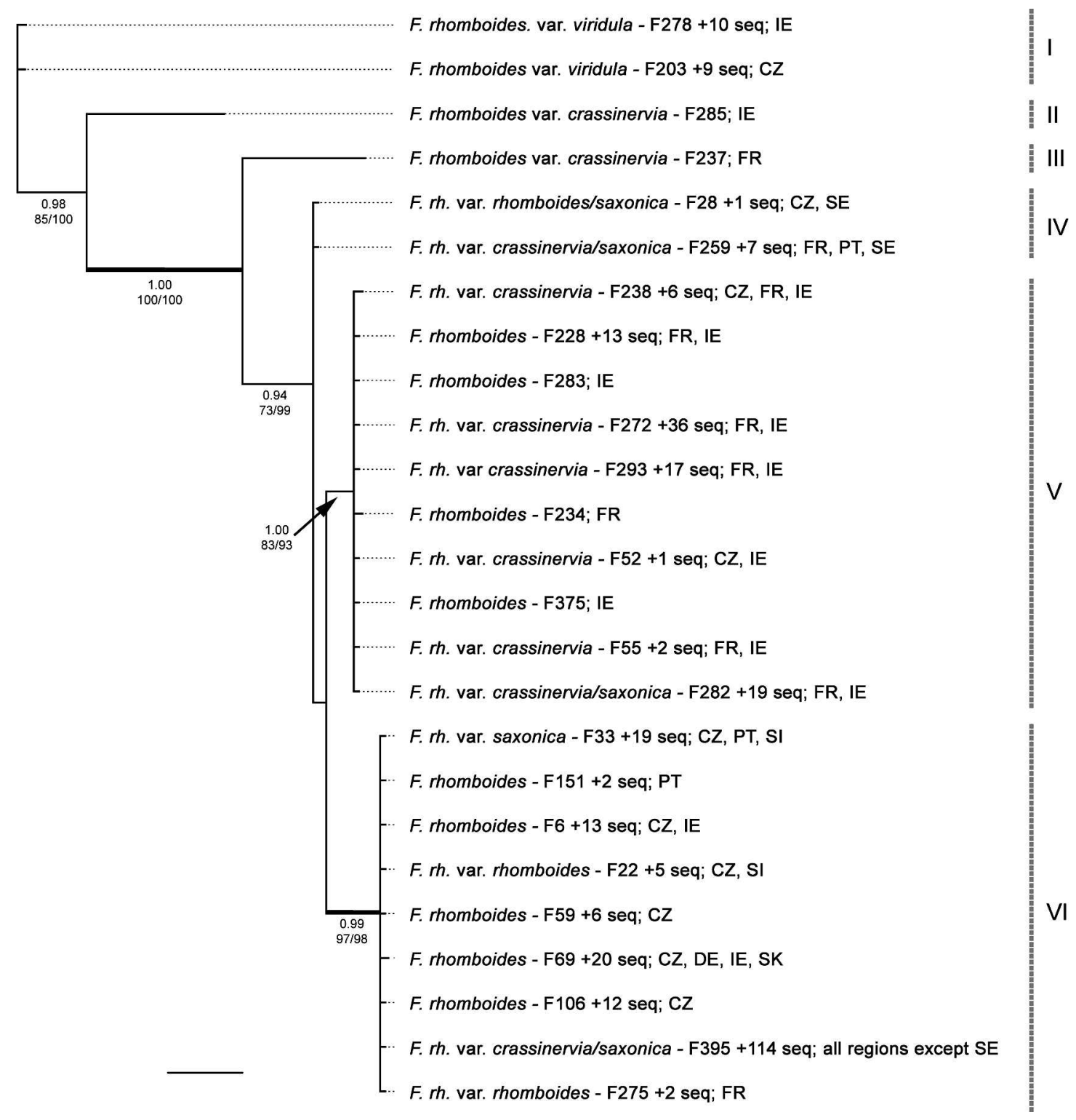

Fig. 1. The Bayesian unrooted tree, based on D1/D2 LSU rDNA sequences of Frustulia rhomboides strains showing six numbered lineages (I-VI). Numbers at the nodes represent Bayesian posterior probability values $(>0.9)$ and bootstrap values $(>50 \%)$ (maximum likelihood/ maximum parsimony). Thick lines indicate branches with posterior probability $>0.95$ in BI and bootstrap support $>90 \%$ in ML and MP. Isolates are identified by strain name (e.g., F278 = strain F278; see Table 1), followed by the number of identical sequences and by the geographic origin of the isolates: The scale bar $=0.2$ substitutions per site.

the background base peaks hampered the recognition of ambiguities, the identification of sequence variants was not possible for all sequences with certainty. A Bayesian tree separated traditional Frustulia rhomboides morphospecies into six phylogenetic lineages (Fig. 1). However, the genetic differentiation did not unambiguously reflect the morphology of the traditional varieties based upon valve dimensions and valve end shapes (Krammer \& Lange-Bertalot 1986).

Table 2. Conventional morphometric data for the six unnamed lineages; measurements based on 11 valves for each selected strain. ${ }^{1}$

\begin{tabular}{lcccrc}
\hline & $\begin{array}{c}\text { Length }(\mu \mathrm{m}), \text { range } \\
(\mathrm{mean} \pm \mathrm{SD})\end{array}$ & $\begin{array}{c}\text { Width }(\mu \mathrm{m}), \text { range } \\
(\mathrm{mean} \pm \mathrm{SD})\end{array}$ & $\begin{array}{c}\text { Length/width, range } \\
(\mathrm{mean} \pm \mathrm{SD})\end{array}$ & $\begin{array}{c}\text { Areolae density } \\
(n / 10 \mu \mathrm{m})\end{array}$ & $\begin{array}{c}\text { Striae density } \\
(n / 10 \mu \mathrm{m})\end{array}$ \\
\hline Lineage I & $79.3-95.9(85.9 \pm 5.7)$ & $15.8-17.6(16.8 \pm 0.5)$ & $4.7-5.8(5.1 \pm 0.3)$ & $24-28$ & 28 \\
Lineage II & $52.0-57.0(54.3 \pm 1.6)$ & $11.2-13.2(12.1 \pm 0.5)$ & $4.0-4.9(4.5 \pm 0.2)$ & $28-32$ & $28-30$ \\
Lineage III & $41.2-50.2(45.0 \pm 3.4)$ & $9.2-12.0(10.4 \pm 0.8)$ & $4.0-4.7(4.3 \pm 0.2)$ & $32-36$ & 32 \\
Lineage IV & $51.8-67.2(59.0 \pm 5.4)$ & $12.7-15.5(13.9 \pm 0.7)$ & $3.7-5.0(4.2 \pm 0.3)$ & $32-36$ & 32 \\
Lineage V & $39.1-68.9(51.4 \pm 8.0)$ & $8.9-13.9(11.6 \pm 1.2)$ & $3.7-5.5(4.4 \pm 0.4)$ & $28-36$ & $32-34$ \\
Lineage VI & $37.3-73.8(51.8 \pm 9.0)$ & $10.6-17.3(13.0 \pm 1.7)$ & $3.3-4.7(4.0 \pm 0.3)$ & $28-36$ \\
\hline
\end{tabular}

\footnotetext{
${ }^{1}$ See Table 1 for strain information.
} 

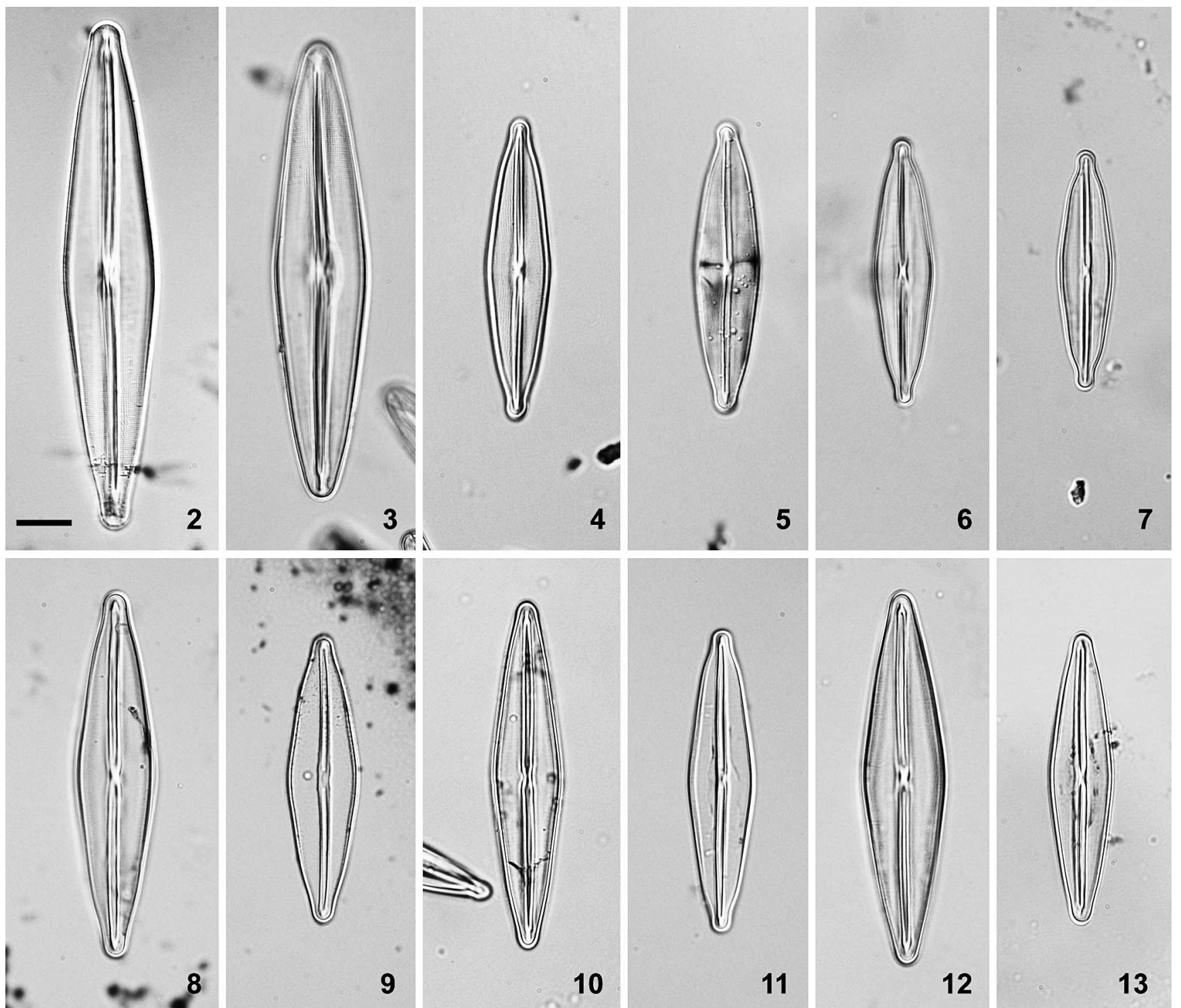

Figs 2-13. Valves of Frustulia rhomboides identified with traditional morphology. Scale bar $=10 \mu \mathrm{m}$.

Figs 2, 3. Lineage I.

Fig. 2. $F$. rhomboides var. viridula. Strain F309.

Fig. 3. F. rhomboides var. viridula. Strain F197.

Figs 4, 5. Lineage II.

Fig. 4. F. rhomboides var. crassinervia. Strain F381.

Fig. 5. F. rhomboides var. crassinervia. Strain F378.

Figs 6, 7. Lineage III.

Fig. 6. F. rhomboides var. crassinervia. Strain F237.

Fig. 7. F. rhomboides var. crassinervia. Strain F331.

Figs 8, 9. Lineage IV.

Fig. 8. F rhomboides. var. crassinervia. Strain F177.

Fig. 9. F. rhomboides var. saxonica. Strain F28.

Figs 10, 11. Lineage V.

Fig. 10. F. rhomboides var. saxonica. Strain F77.

Fig. 11. F. rhomboides var. crassinervia. Strain F215.

Figs 12, 13. Lineage VI.

Fig. 12. F. rhomboides var. rhomboides. Strain F288.

Fig. 13. F. rhomboides var. saxonica. Strain F297.

Cells from lineage I had larger dimensions, coarse striae (Table 2), and characteristic shapes (outline and raphe); they were identified as $F$. rhomboides var. viridula (Figs 2, 3). Cells from lineages II and III were generally smaller and had more-or-less rostrate ends; they corresponded to $F$. rhomboides var. crassinervia (Figs 4-7). However, cells from lineage II differed from other crassinervia-like strains by their coarser striae pattern and by their valve ends being slightly bent on opposite sides (Figs 4, 5). Cells from lineages IV-VI had variable dimensions with rostrate or 
Table 3. Pairwise comparisons between lineages III-VI (lower diagonal), ${ }^{1}$ based on the length data (upper row) and the length/ breadth data (lower row). Remaining part of the matrix quantified shape similarities between the lineages. The percentage of correctly classified cells is in diagonal. The Mahalanobis squared distances (upper row) and the sum of percentage of misidentified cells (lower row) is in the upper diagonal.

\begin{tabular}{|c|c|c|c|c|}
\hline & $\begin{array}{l}\text { Lineage } \\
\text { III }\end{array}$ & $\begin{array}{l}\text { Lineage } \\
\text { IV }\end{array}$ & $\begin{array}{c}\text { Lineage } \\
\mathrm{V}\end{array}$ & $\begin{array}{c}\text { Lineage } \\
\text { VI }\end{array}$ \\
\hline Lineage III & $86.7 \%$ & $\begin{array}{l}\mathrm{d}^{2}=16.5 \\
5.0 \%\end{array}$ & $\begin{array}{l}\mathrm{d}^{2}=15.1 \\
12.5 \%\end{array}$ & $\begin{array}{l}d^{2}=25.6 \\
0 \%\end{array}$ \\
\hline Lineage IV & $\begin{array}{l}\mathrm{p}_{1}^{* * *} \\
\mathrm{p}_{1 / \mathrm{w}} \mathrm{ns}\end{array}$ & $78.3 \%$ & $\begin{array}{l}\mathrm{d}^{2}=3.8 \\
25.6 \%\end{array}$ & $\begin{array}{l}\mathrm{d}^{2}=4.7 \\
22.8 \%\end{array}$ \\
\hline Lineage $\mathrm{V}$ & $\begin{array}{l}\mathrm{p}_{\mathrm{l}} \mathrm{ns} \\
\mathrm{p}_{\mathrm{l} / \mathrm{w}} \mathrm{ns}\end{array}$ & $\begin{array}{l}\mathrm{p}_{1}^{* * *} \\
\mathrm{p}_{1 / \mathrm{w}} *\end{array}$ & $76.1 \%$ & $\begin{array}{l}\mathrm{d}^{2}=6.9 \\
15.8 \%\end{array}$ \\
\hline Lineage VI & $\begin{array}{l}\mathrm{p}_{1}^{* *} \\
\mathrm{p}_{1 / \mathrm{w}} * * *\end{array}$ & $\begin{array}{l}\mathrm{p}_{1}^{* * * *} \\
\mathrm{p}_{\mathrm{l} / \mathrm{w}} *\end{array}$ & $\begin{array}{l}\mathrm{p}_{1} \mathrm{~ns} \\
\mathrm{p}_{\mathrm{l} / \mathrm{w}} * * *\end{array}$ & $77.2 \%$ \\
\hline
\end{tabular}

${ }^{1}$ ns (not significant), $P>0.05$.

${ }^{*} P<0.05$.

$* * P<0.01$.

$* * * P<0.001$

protracted valve ends; these resembled $F$. rhomboides var. saxonica, $F$. rhomboides var. crassinervia, or $F$. rhomboides var. rhomboides (Figs 8-13).

Ultrastructural features of the raphe endings were similar among all lineages; the external raphe fissures were $\mathrm{T}$ shaped, and the internal raphe sternum ribs formed a portecrayon structure at the apical ends of the valve (figures not shown). Because the cellular morphology in lineages III-VI was ambiguous, morphometric analyses were employed to quantify the morphological variability. Even though the ranges of the traditional morphometric data were broadly overlapping among lineages (Table 2), there were significant differences between mean values (Mann-Whitney pairwise comparison tests). Valve breadth was significantly different among all pairs of lineages $(P<0.001)$, and pairwise comparisons, in many cases, were also significant for valve lengths, as well as the length to breadth ratios (Table 3). A combination of valve length and breadth measurements discriminated between all pairs of lineages $(P<0.001$,
NPMANOVA), except lineages V and VI. Subsequently, strains of lineages III-VI were analysed by geometric morphometric techniques, which quantified the nonallometric shape variability of the valves. Although both NPMANOVA and CVA significantly differentiated all the pairs of lineages $(P<0.001$; Wilks' lambda $=0.14)$, the PCA diagram (Figs 14, 15) and comparisons based on Mahalanobis distances (Table 3) showed substantial overlaps in the shape characteristics of cells belonging to different lineages. Interestingly, those strains that were isolated from the same locality were separated along the first PC axis according to their genetic divergence, and they did not cluster together (Fig. 15). Even though $\mathrm{pH}$ values of the culture medium were not standardized, the ordination diagram did not reflect the $\mathrm{pH}$ gradient. The thin plate spline method was used for reconstruction of the mean valve shapes within individual lineages. Mean valve shapes were also reconstructed for four strains from lineages V and VI with positions intermediate to the clusters representing the morphological variation zof the phylogenetic lineages. Visualizations of the mean valve shapes indicated that strains of lineages IV and VI had a broadly lanceolate valve shape (Figs 16-18); valves of lineages V and VI were narrowly lanceolate (Figs 19-21); and members of lineages III and V had mostly rostrate apical ends (Figs 22, 23).

Frustulia rhomboides lineages showed different patterns of geographic distribution within the studied area (Table S1; Fig. 24). Strains of lineages I, III, and IV had a scattered distribution. Strains of lineage II were found at a single locality in Ireland. Strains of lineage V dominated the Irish and French collection localities, while strains of lineage VI were widely distributed. The Mantel tests of correlations between the frequencies of all lineages and abiotic factors were significant $(P<0.01)$ for geographic distance (negative correlation) and for biotope type (positive correlation); statistical correlation was still significant $(P<0.01)$ after removal of the third matrix correlation, which was stepwise selected from the other distance matrices. Sequence frequencies of all lineages were not significantly correlated
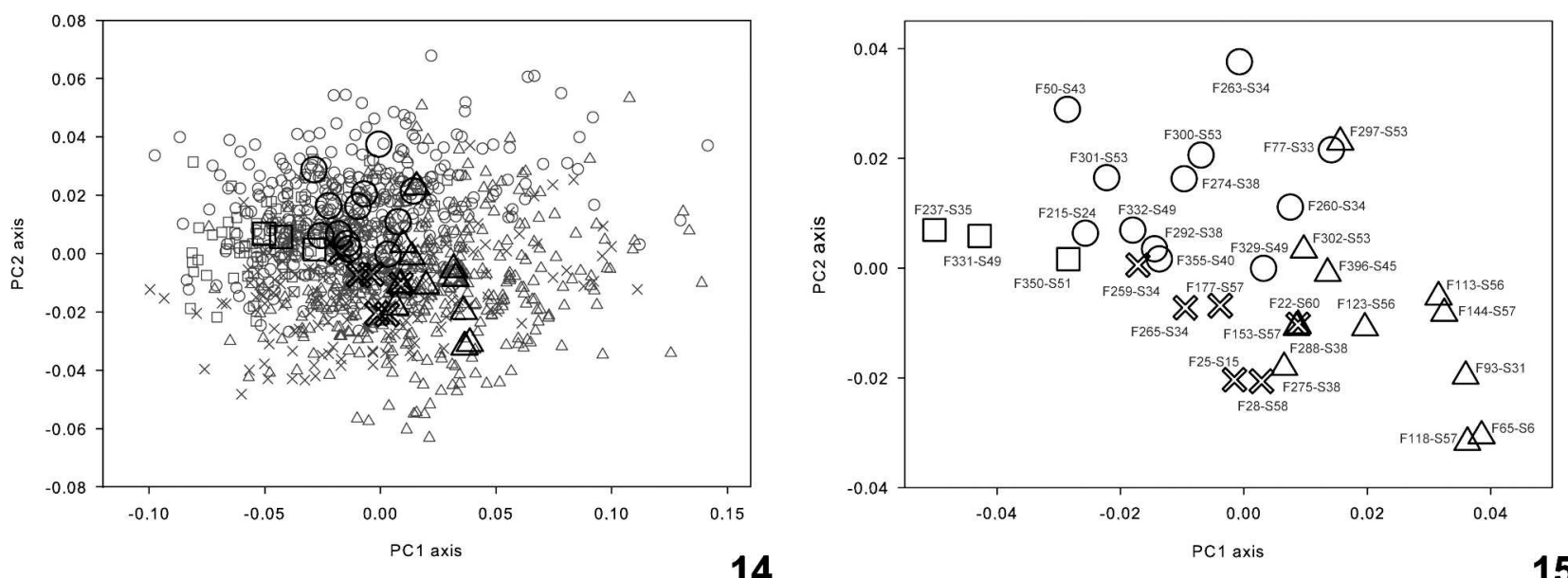

Figs 14-15. Principal component analysis based on the valve shape characteristics for lineages III-VI. The first and second principal components accounted for $75.6 \%$ and $20.4 \%$ of the total variance. $\square=$ lineage III; X $=$ lineage IV; $\bigcirc=$ lineage V; $\triangle=$ lineage VI. See Table S1 for sampling sites, Table 1 for strain information.

Fig. 14. Positions of cells (smaller symbols) and centroids of the individual strains (larger symbols).

Fig. 15. Detailed view of centroid positions. 

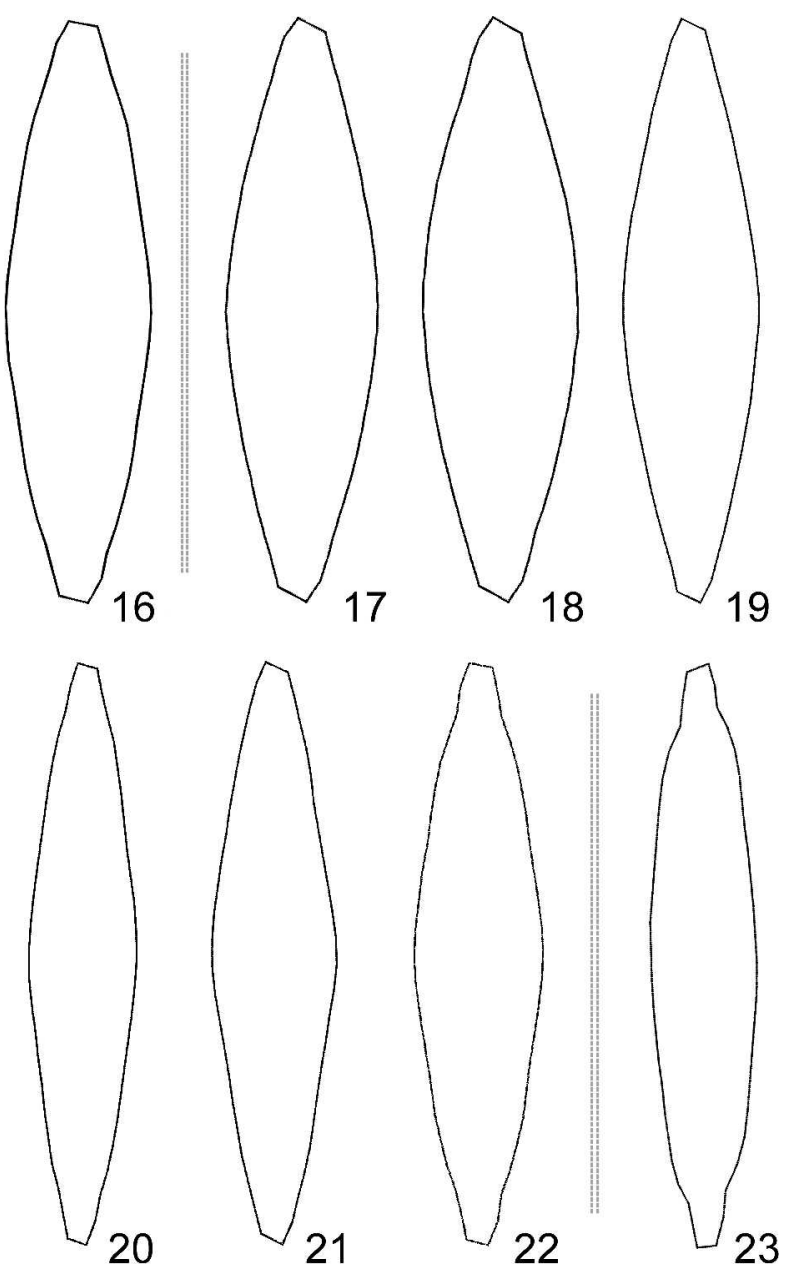

Figs 16-23. Characteristic shapes of the lineages and strains visualised by the thin plate spline method, as deformations from the overall mean configuration of landmarks of the entire dataset. Deformations were enlarged $\times 3$ for the lineages and $\times 2$ for the strains. The straight lines between $16-17$ and $22-23$ separate the images of different lineages.

Fig. 16. Characteristic configuration of lineage IV.

Figs 17-19. Lineage VI.

Fig. 17. Characteristic lineage configuration.

Fig. 18. Characteristic shape for strain F93.

Fig. 19. Characteristic shape for strain F396.

Figs 20-22. Lineage $\mathrm{V}$.

Fig. 20. Characteristic lineage configuration.

Fig. 21. Characteristic shape for strain F260.

Fig. 22. Characteristic shape for strain F355.

Fig. 23. Characteristic configuration of lineage III.

$(P>0.05)$ with climatic characteristics (altitude, temperature) or water characteristics ( $\mathrm{pH}$, conductivity); however, the importance of the environmental factors associated with habitat types was obvious. All strains from ephemeral habitats, collected from distant localities, occurred primarily in lineage I or VI. Furthermore, sampling sites separated by a few meters but differing in $\mathrm{pH}$, conductivity, and habitat type (S37 and S38; S41 and S42; S45 and S47) also differed in the sequence frequencies of the lineages (Table S1). Sampling sites dominated by lineage $\mathrm{V}$ had significantly higher values of $\mathrm{pH}(P<0.001 ; \bar{X}=6.6)$ and conductivity $(P$ $<0.01 ; \bar{X}=121)$ when compared with lineage $\mathrm{VI}(\bar{X} \mathrm{pH}=$ 4.8; $\bar{X}$ conductivity $=47$ ).

\section{DISCUSSION}

A multidisciplinary approach to species-level taxonomy has indicated that hidden diversity within diatom morphospecies might not be recognizable with the naked eye (Mann et al. 2004; Mann \& Evans 2007) and/or the morphological similarity of phylogenetic lineages might not agree with their genetic distances (Alverson 2008; Evans et al. 2008; Trobajo et al. 2009). In our study, the morphology of four closely related lineages of Frustulia rhomboides could be characterized only on the basis of morphometric analyses. Morphological features used to distinguish traditional varieties (i.e. $F$. rhomboides var. crassinervia and $F$. rhomboides var. saxonica) occurred across molecular phylogenetic lineages. Incongruence between traditional morphology and molecular datasets might have been influenced by the size reduction of diatom frustules during the life cycle (i.e. large cells gradually reducing to small cells; sexual reproduction and auxospore formation; return to large cell size). Shape differences between large and small cells of monoclonal cultures might override the differences between species (Veselá et al. 2009) because frustule shape does not diminish proportionally as frustule size is reduced (Round et al. 1990; Edlund \& Stoermer 1997). Because traditional varieties of $F$. rhomboides are mostly distinguished by size and shape (Krammer \& Lange-Bertalot 1986), small cells with protracted apical ends might actually represent the stages of the life cycle ( $F$. rhomboides var. saxonica) as well as another taxon ( $F$. rhomboides var. crassinervia). In addition to changes in cell size and shape during the life cycle, phenotypic plasticity may be induced by environmental conditions, and this plasticity may mask the morphological signal traditionally used for species identification (Mann 1999; Kociolek \& Stoermer 2010). Nonetheless, geometric morphometric studies of monoclonal diatom cultures demonstrated that shape variation could be relatively high and overlapping for closely related strains and lineages, even though the strains were cultivated under stable experimental conditions and the allometric components of the shape variation were reduced in the morphometric analyses (Veselá et al. 2009; Poulíčková et al. 2010). A similar pattern was found in our study. Despite significant differences between the mean shapes of closely related lineages, morphological identification of individual cells would hardly be possible based upon frustule outlines. We cannot exclude the possibility that some ultrastructural (Amato et al. 2007) or cytological features (Poulíčková et al. 2010) may discriminate the individual cells into the $F$. rhomboides molecular phylogenetic lineages.

Recent studies suggested that diatom rDNA sequences may fail to discriminate among closely related species because high copy number and intraclonal polymorphism can obscure species boundaries (reviewed by Alverson 2008). In our study, the D1/D2 LSU rDNA sequences showed relatively high intraclonal sequence variation that complicated the reconstruction of phylogeny. Because DNA polymorphism may indicate incomplete lineage sorting, recent hybridization among lineages, and/or heterozygosity of diploid populations (Clark 1990; Sonnenberg et al. 2007; Alverson 2008; D’Alelio et al. 2009), we 


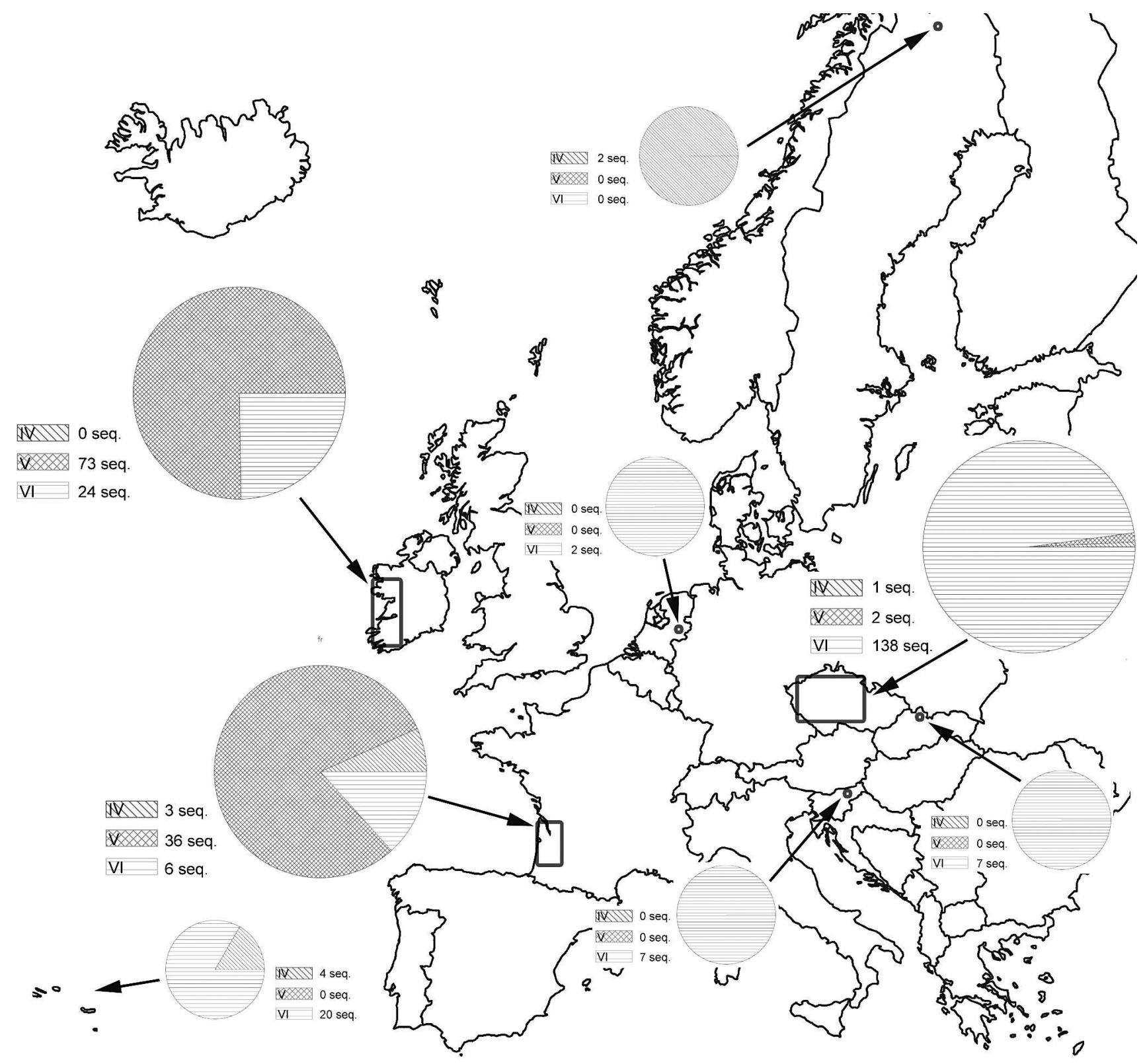

Fig. 24. Pie charts showing the distributional proportions for lineages IV-VI. The sampling areas, pie chart sizes, and sequence numbers for individual lineages indicate the variable sampling efforts.

decided not to describe our lineages as separate species on the basis of partial LSU data. A multilocus phylogeny combined with other approaches may be more appropriate for taxonomic conclusions among the closely related Frustulia rhomboides lineages.

Although it has been assumed that the hidden diversity of traditional protist species is accompanied by physiological, ecological, and/or geographic differentiation (Amato et al. 2007; Mann \& Evans 2007), few diatom studies have investigated these aspects. The case studies on sibling species have suggested that diatoms may be either widely distributed within a particular climatic zone or narrowly restricted within a geographic region (Casteleyn et al. 2008; Kooistra et al. 2008; Mann et al. 2008). Our study also showed different distribution patterns, even within a relatively small geographic area. The members of lineage II and III were only recorded in western Ireland and/or Aquitaine. Conversely, some lineages had a wide geographic distribution, including the rarely encountered lineages I and IV as well as the frequently encountered lineages V and VI. Lineage V predominated in the western localities but it was also rarely present in eastern areas. According to the statistical tests, sequence frequencies of Frustulia rhomboides lineages were significantly correlated with the geographic distances and habitat type. We suggest that the frequencies can be explained by specific environmental requirements rather than by dispersal constraints. In particular, lineages $\mathrm{V}$ and VI were most likely associated with different habitat types in two geographic areas. Lineage $\mathrm{V}$ predominated in the western area, which was mostly represented by circumneutral lakes. On the other hand, samples from eastern localities, which were dominated by lineage VI, were mostly 
taken from acidic habitats. Similar results have also been obtained in the long-term studies of Sellaphora sibling species, with some species having specific environmental requirements with respect to $\mathrm{pH}$ and trophic status (Mann et al. 2008; Poulíčková et al. 2008). In addition, Créach et al. (2006) and Vanelslander et al. (2009) also illustrated that the distribution frequencies of individual Navicula phyllepta Kützing sibling species reflected differences in their ecological preferences. Since molecular genetic analyses need an incomparably larger effort in comparison with studies based on morphological features, morphometric techniques has been used to assess the identity and variability of natural populations with respect to the morphology of the type specimens (Potapova \& Hamilton 2007; Fránková et al. 2009) or the phylogeny of the species complexes (Vanelslander et al. 2009; Neustupa et al. 2011). It is likely that morphometric methods also could be used for the estimation of distribution and ecology of pseudocryptic Frustulia rhomboides lineages on the basis of natural assemblages because the mean morphological features differed between lineages. Therefore, it would be possible to compare by means of statistical analyses morphological variation of natural populations with the morphology of Frustulia rhomboides lineages.

In conclusion, the phylogenetic lineages recovered in this study did not fully correspond to traditionally recognized subspecific taxa of the Frustulia rhomboides complex. The geographic distribution of frequently occurring pseudocryptic lineages within $F$. rhomboides most likely reflected their different environmental requirements. Considering the results of our study, future polyphasic taxonomic revision of the genus Frustulia would apparently require the description of several species within the traditional $F$. rhomboides.

\section{ACKNOWLEDGEMENTS}

We thank colleagues from the phycological research group for their help with the sampling. We are grateful to the reviewers for their valuable comments and suggestions. Funding of this work was provided by Research Project 0021620828 of the Czech Ministry of Education and by the Charles University Science Foundation Project B-Bio 30108.

\section{SUPPLEMENTARY DATA}

Supplementary data associated with this article can be found in the online version, at doi: 10.2116/11-101.1.

\section{REFERENCES}

Alverson A.J. 2008. Molecular systematics and the diatom species. Protist 159: 339-353.

Amato A., Kooistra W.H.C.F., Ghiron L.J.H., Mann D.G., Pröschold T. \& Montresor M. 2007. Reproductive isolation among sympatric cryptic species in marine diatoms. Protist 158: 193-207.

Battarbee R.W., Jones V.J., Flower R.J., Cameron N.G., Bennion H., Carvalho L. \& Juggins S. 2001. Diatoms. In: Tracking environmental change using lake sediments. Volume 3: terrestrial, algal, and siliceous indicators (Ed. by J.P. Smol, H.J.B. Birks \& W.M. Last), pp. 155-202. Kluwer Academic Publishers, Dordrecht, the Netherlands.
Behnke A., Friedl T., Chepurnov V.A. \& Mann D.G. 2004. Reproductive compatibility and rDNA sequence analyses in the Sellaphora pupula species complex (Bacillariophyta). Journal of Phycology 40: 193-208.

Beier T. \& LAnge-Bertalot H. 2007. A synopsis of cosmopolitan, rare and new Frustulia species (Bacillariophyceae) from ombrotrophic peat bogs and minerotrophic swamps in New Zealand. Nova Hedwigia 85: 73-91.

Beszteri B., Ács E. \& Medlin L.K. 2005. Ribosomal DNA sequence variation among sympatric strains of the Cyclotella meneghiniana complex (Bacillariophyceae) reveals cryptic diversity. Protist 156: 317-333.

Boenigk J., Jost S., Stoeck T. \& Garstecki T. 2007. Differential thermal adaptation of clonal strains of a protist morphospecies originating from different climatic zones. Environmental Microbiology 9: 593-602.

Bonnet E. \& VAn de Peer Y. 2002. ZT: a software tool for simple and partial Mantel tests. Journal of Statistical Software 7: 1-12.

BoOKSTEIN F.L. 1997. Landmark methods for forms without landmarks: morphometrics of group differences in outline shape. Medical Image Analysis 1: 225-243.

Casteleyn G., Chepurnov V.A., Leliaert F., Mann D.G., Bates S.S., Lundholm N., Rhodes L., Sabbe K. \& Vyverman W. 2008. Pseudo-nitzschia pungens (Bacillariophyceae): a cosmopolitan diatom species? Harmful Algae 7: 241-257.

Clark A.G. 1990. Inference of haplotypes from PCR-amplified samples of diploid populations. Molecular Biology and Evolution 7: $111-122$.

Créach V., Ernst A., Sabbe K., Vanelslander B., Vyverman W. \& STAL L.J. 2006. Using quantitative PCR to determine the distribution of a semicryptic benthic diatom, Navicula phyllepta (Bacillariophyceae). Journal of Phycology 42: 1142-1154.

D'alelio D., Amato A., Kooistra W.H.C.F., Procaccini G., CAsotti R. \& Montresor M. 2009. Internal transcribed spacer polymorphism in Pseudo-nitzschia multistriata (Bacillariophyceae) in the Gulf of Naples: recent divergence or intraspecific hybridization? Protist 160: 9-20.

DE QueIroz, K. 2005. Ersnt Mayr and the modern concept of species. Proceedings of the National Academy of Sciences 102: 6600-6607.

DE QueIRoz, K. 2007. Species concepts and species delimitation. Systematic Biology 56: 879-886.

Edgar S.M. \& Theriot E.C. 2004. Phylogeny of Aulacoseira (Bacillariophyta) based on molecules and morphology. Journal of Phycology 40: 772-788.

EdLund M.B. \& Stoermer E.F. 1997. Ecological, evolutionary, and systematic significance of diatom life histories. Journal of Phycology 33: 897-918.

Evans K.M., Wortley A.H., Simpson G.E., Chepurnov V.A. \& MANN D.G. 2008. A molecular systematic approach to explore diversity within the Sellaphora pupula species complex (Bacillariophyta). Journal of Phycology 44: 215-231.

FENCHEL T. 2005. Cosmopolitan microbes and their "cryptic" species. Aquatic Microbial Ecology 41: 49-54.

FENCHEL T. \& Finlay B.J. 2006. The diversity of microbes: resurgence of the phenotype. Philosophical Transactions of the Royal Society B 361: 1695-1973.

Fránková M., Poulíčková A., Neustupa J., Pichrtová M. \& MARVAN P. 2009. Geometric morphometrics - a sensitive method to distinguish diatom morphospecies: a case study on the sympatric populations of Reimeria sinuata and Gomphonema tergestinum (Bacillariophyceae) from the River Bečva, Czech Republic. Nova Hedwigia 88: 81-95.

HAMmer Ø., HARPer D.A.T. \& RyAN P.D. 2001. PAST: paleontological statistics software package for education and data analysis. Palaeontologia Electronica 4: 1-9.

Huelsenbeck J.P. \& Ronquist F. 2001. MRBAYES: Bayesian inference of phylogeny. Bioinformatics 17: 754-755.

Kociolek J.P. \& StOermer E.F. 2010. Variation and polymorphism in diatoms: the triple helix of development, genetics and environment. A review of the literature. Vie Et Milieu 60: 75-87.

Kooistra W.H.C.F., Sarno D., Balzano S., Gu H., Andersen R.A. \& ZINGONE A. 2008. Global diversity and biogeography of Skeletonema species (Bacillariophyta). Protist 159: 177-193. 
Krammer K. \& Lange-Bertalot H. 1986. Bacillariophyceae 1. Teil: Naviculaceae. In: Süsswasserflora von Mitteleuropa, Vol. 2/1 (Ed. by H. Ettl, J. Gerloff, H. Heynig \& D. Mollenhauer), G. Fischer, Stuttgart, Germany. 876 pp.

Kumar S., Dudley J., Nei M. \& Tamura K. 2008. MEGA: a biologist-centric software for evolutionary analysis of DNA and protein sequences. Briefings in Bioinformatics 9: 299-306.

LANGE-Bertalot H. 2001. Navicula sensu stricto. 10 genera separated from Navicula sensu lato. Frustulia. In: Diatoms of Europe, Vol. 2 (Ed. by H. Lange-Bertalot), A.R.G. Gantner, Ruggell, Liechtenstein. 526 pp.

LANGE-BERTALOT H. \& JAHN R. 2000. On the identity of Navicula (Frustulia) rhomboides and Frustulia saxonica (Bacillariophyceae). Systematics and Geography of Plants 70: 255-261.

LANGe-Bertalot H. \& Metzeltin D. 1996. Indicators of oligotrophy. In: Iconographia Diatomologica, Vol. 2 (Ed. by H. Lange-Bertalot), Koeltz, Königstein, Germany. 390 pp.

Lowe C.D., Day A., Kemp S.J. \& Montagnes D.J.S. 2005a. There are high levels of functional and genetic diversity in Oxyrrhis marina. Journal of Eukaryotic Microbiology 52: 250-257.

Lowe C.D., Kemp S.J. \& Montagnes D.J.S. 2005b. An interdisciplinary approach to assess the functional diversity of free-living microscopic eukaryotes. Aquatic Microbial Ecology 41: 67-77.

Mann D.G. 1999. The species concept in diatoms. Phycologia 38: 437-495.

ManN D.G. 2010. Discovering diatom species: is a long history of disagreements about species-level taxonomy now at the end? Plant Ecology and Evolution 143: 251-264.

MANN D.G. \& Evans K. 2007. Molecular genetics and the neglected art of diatomics. In: Unravelling the algae: the past, present, and future of algal systematics (Ed. by J. Brodie \& $\mathrm{J}$. Lewis), pp. 231-265. CRC Press, Taylor \& Francis group, Boca Raton, Florida.

Mann D.G., McDonald S.M., Bayer M.M., Droop S.J.M., Chepurnov V.A., Loke R.E., Ciobanu A. \& du Buf J.M.H. 2004. The Sellaphora pupula species complex (Bacillariophyceae): morphometric analysis, ultrastructure and mating data provide evidence for five new species. Phycologia 43: 459-482.

Mann D.G., Thomas S.J. \& Evans K.M. 2008. Revision of the diatom genus Sellaphora: a first account of the larger species in the British Isles. Fottea 8: 15-78.

Neustupa J., ŠŤastný, J., Nemjová K., Mazalová P., Goodyer E., PoulíčKová A. \& Š́kaloud, P. 2011. A novel, combined approach to assessing species delimitation and biogeography within the well-known desmid species Micrasterias fimbriata and M. rotata (Desmidiales, Steptophyta). Hydrobiologia 667: 223-239.

NYLANDER J.A.A. 2004. MrModeltest v2. Available at: http://www. abc.se/ nylander (12 March 2011).

Philippe H., Sorhannus U., Baroin A., Perasso R., Gasse F. \& Adoutte A. 1994. Comparison of molecular and paleontological data in diatoms suggests a major gap in the fossil record. Journal of Evolutionary Biology 7: 247-265.

Potapova M. \& Hamilton P.B. 2007. Morphological and ecological variation within the Achnanthidium minutissimum (Bacillariophyceae) species complex. Journal of Phycology 43: 561-575.

PoulíčKová A., ŠpačKová, J., Kelly M.G., Duchoslav M. \& MANN D.G. 2008. Ecological variation within Sellaphora species complexes (Bacillariophyceae) - specialists or generalists? Hydrobiologia 614: 373-386.

PoulíčKová A., Veselá J., Neustupa J. \& ŠKaloud, P. 2010. Pseudocryptic diversity versus cosmopolitanism in diatoms: a case study on Navicula cryptocephala Kütz. (Bacillariophyceae) and morphologically similar taxa. Protist 161: 353-369.

Pröschold T. \& Leliaert F. 2007. Systematics of the green algae: conflict of classic and modern approaches. In: Unravelling the algae: the past, present, and future of algal systematics (Ed. by J. Brodie \& J. Lewis), pp. 123-153. CRC Press, Taylor \& Francis group, Boca Raton, Florida.
R Development Core Team. 2008. $R$ : A Language and Environment for Statistical Computing. Available at: http://www.Rproject.org (4 April 2009).

RohLF F.J. 2010. TPS Series. Available at: http://life.bio.sunysb. edu/morph/ (1 May 2012).

Round F.E., CRAWFORD R.M. \& MANN D.G. 1990. The diatoms: biology and morphology of the genera. Cambridge University Press, Cambridge, UK. 758 pp.

Sato S., Kooistra W.H.C.F., Watanabe T., Matsumoto S. \& MedLin L.K. 2008. A new araphid diatom genus Psammoneis gen. nov. (Plagiogrammaceae, Bacillariophyta) with three new species based on SSU and LSU rDNA sequence data and morphology. Phycologia 47: 510-528.

Seibel P.N., Müller T., Dandekar T., Schultz J. \& Wolf M. 2006. 4SALE - a tool for synchronous RNA sequence and secondary structure alignment and editing. BMC Bioinformatics 7 : 498.

Seibel P.N., Müller T., Dandekar T. \& Wolf M. 2008. Synchronous visual analysis and editing of RNA sequence and secondary structure alignments using 4SALE. BMC Research Notes 1: 91.

Siver P.A. \& BAskette G. 2004. A morphological examination of Frustulia (Bacillariophyceae) from the Ocala National Forest, Florida, USA. Canadian Journal of Botany 82: 629-644.

ŠKAlOud P. \& PEKSA O. 2010. Evolutionary inferences based on ITS rDNA and actin sequences reveal extensive diversity of the common lichen alga Asterochloris (Trebouxiophyceae, Chlorophyta). Molecular Phylogenetics and Evolution 54: 36-46.

Sonnenberg R., Nolte A.W. \& TAutz D. 2007. An evaluation of LSU rDNA D1-D2 sequences for their use in species identification. Frontiers in Zoology 4: 6.

SwOFFORD D.L. 2001. PAUP*: phylogenetic analysis using parsimony (*and other methods), Version 4. Sinauer Associates, Sunderland, Massachusetts.

Trobajo R., Clavero E., Chepurnov V.A., Sabbe K., Mann D.G., Ishihara S. \& Cox E.J. 2009. Morphological, genetic and mating diversity within the widespread bioindicator Nitzschia palea (Bacillariophyceae). Phycologia 48: 443-459.

VAnelslander B., Créach V., VAnormelingen P., ERnst A., Chepurnov V.A., Sahan E., Muyzer G., Stal L.J., Vyverman W. \& SABBE K. 2009. Ecological differentiation between sympatric pseudocryptic species in the estuarine benthic diatom Navicula phyllepta (Bacillariophyceae). Journal of Phycology 45: $1278-1289$.

Veselá J., Neustupa J., Pichrtová M. \& Poulíč́ová A. 2009 Morphometric study of Navicula morphospecies (Bacillariophyta) with respect to diatom life cycle. Fottea 9: 307-316.

WEHR J.D. \& SHEATH R.G. 2002. Freshwater habitats of algae. In: Freshwater algae from North America; ecology and classification (Ed. by J.D. Wehr \& R.G. Sheath), pp. 11-57. Elsevier Science, San Diego, California, USA.

WeIsSE T. 2008. Distribution and diversity of aquatic protists: an evolutionary and ecological perspective. Biodiversity and Conservation 17: 243-259.

Weisse T., Strüder-Kypke M.C., Berger H. \& Foissner W. 2008. Genetic, morphological, and ecological diversity of spatially separated clones of Meseres corlissi Petz \& Foissner, 1992 (Ciliophora, Spirotrichea). Journal of Eukaryotic Microbiology 55: 257-270.

YeunG P.K.K., KONG K.F., Wong F.T.W. \& Wong J.T.Y. 1996 Sequence data for two large-subunit rRNA genes from an Asian strain of Alexandrium catenella. Applied and Environmental Microbiology 62: 4199-4201.

ZWICKL D.J. 2006. Genetic algorithm approaches for the phylogenetic analysis of large biological sequence datasets under the maximum likelihood criterion. Ph.D. dissertation. University of Texas at Austin USA. 115 pp.

Received 11 October 2011; accepted 21 February 2012 
Table S1. Sample sites, their environmental characteristics and their sequence frequencies of lineages.

\begin{tabular}{|c|c|c|c|c|c|c|c|c|c|c|c|c|}
\hline $\begin{array}{l}\text { Sam- } \\
\text { ple }\end{array}$ & habitat & locality & $\begin{array}{l}\text { sample } \\
\text { date }^{1}\end{array}$ & region $^{2}$ & \multicolumn{2}{|c|}{ GPS coordinates $^{3}$} & $\begin{array}{l}\text { alti- } \\
\text { tude } \\
\text { (m) }\end{array}$ & $\mathrm{pH}$ & $\begin{array}{l}\text { condu- } \\
\text { ctivity } \\
\left(\mu \mathrm{S} \cdot \mathrm{cm}^{-2}\right)\end{array}$ & $\begin{array}{c}t_{\min } \text { to } \\
t_{\max }{ }^{4}\left({ }^{\circ} \mathrm{C}\right)\end{array}$ & $\begin{array}{c}\text { no. of } \\
\text { freezing } \\
\text { days }\end{array}$ & $\begin{array}{l}\text { lineages and } \\
\text { no. of } \\
\text { sequences }^{5}\end{array}$ \\
\hline S1 & pool & Babin & Nov-07 & $\mathrm{CZ}$ & 49.541126 & 15.896039 & 565 & 5.0 & 70 & -17 to 25 & 82 & VI:1 \\
\hline S2 & pool & Babin & Oct-09 & CZ & 49.541126 & 15.896039 & 565 & $\mathrm{NA}^{7}$ & NA & -17 to 25 & 82 & VI:8 \\
\hline S3 & mire & Borkovicka blata & Mar-08 & CZ & 49.236267 & 14.622583 & 417 & NA & NA & -15 to 31 & 74 & VI:1 \\
\hline S4 & mire & Borkovicka blata & Oct-09 & $\mathrm{CZ}$ & 49.236267 & 14.622583 & 417 & 5.2 & NA & -15 to 31 & 74 & VI:6 \\
\hline S5 & small pool ${ }^{6}$ & Cinovecke r. & Aug-09 & CZ & 50.722881 & 13.742694 & 876 & 5.2 & 20 & -17 to 25 & 100 & VI:2 \\
\hline S6 & small pool ${ }^{6}$ & Cinovecke r. & Aug-09 & CZ & 50.723033 & 13.742755 & 876 & 4.4 & 14 & -17 to 25 & 100 & VI:5 \\
\hline S7 & peat bog & Hochmoor & Aug-09 & $\mathrm{DE}$ & 50.730663 & 13.741953 & 863 & 4.7 & 34 & -17 to 25 & 100 & VI:5 \\
\hline S8 & mire & Hlinir & Oct-10 & $\mathrm{CZ}$ & 49.237804 & 14.630472 & 428 & 4.2 & 111 & -15 to 31 & 74 & VI:18 \\
\hline S9 & wet wall & near Hrensko & Oct-10 & $\mathrm{CZ}$ & 50.87405 & 14.241436 & 148 & NA & NA & -13 to 29 & 56 & VI:6 \\
\hline S10 & peat bog & Na Cihadle & Sep-08 & $\mathrm{CZ}$ & 50.833317 & 15.23087 & 972 & 4.3 & 21 & -17 to 24 & 106 & VI:1 \\
\hline S11 & peat bog & Na Cihadle & Oct-09 & $\mathrm{CZ}$ & 50.833317 & 15.23087 & 972 & 3.7 & 44 & -17 to 24 & 106 & VI:5 \\
\hline S12 & peat bog & Klecove louky & Oct-08 & $\mathrm{CZ}$ & 50.83111 & 15.246694 & 985 & 4.2 & 45 & -17 to 24 & 106 & VI:4 \\
\hline S13 & peat bog & Klecove louky & Nov-09 & CZ & 50.831319 & 15.244377 & 986 & 4.0 & 45 & -17 to 24 & 106 & VI:1 \\
\hline S14 & peat bog & Vyhlidkova louka & Oct-08 & CZ & 50.827778 & 15.327778 & 866 & 4.6 & 25 & -16 to 25 & 95 & VI:2 \\
\hline
\end{tabular}




\begin{tabular}{|c|c|c|c|c|c|c|c|c|c|c|c|c|}
\hline S15 & peat bog & Klugeho louka & Oct-08 & $C Z$ & 50.828056 & 15.328056 & 867 & 4.5 & 25 & -16 to 25 & 95 & IV:1; VI:3 \\
\hline S16 & small pool ${ }^{6}$ & drainage canal & Nov-09 & $C Z$ & 50.836944 & 15.246694 & 975 & 4.0 & 52 & -17 to 24 & 106 & Vl:6 \\
\hline S17 & small pool ${ }^{6}$ & drainage canal & Nov-09 & $C Z$ & 50.836327 & 15.245833 & 975 & 4.3 & 45 & -17 to 24 & 106 & $\mathrm{Vl}: 10$ \\
\hline S18 & wet wall & near Stolpissky v. & Nov-09 & $\mathrm{CZ}$ & 50.851128 & 15.194167 & 795 & NA & NA & -16 to 25 & 95 & I:6 \\
\hline S19 & wet wall & near Stolpissky v. & Oct-08 & $\mathrm{CZ}$ & 50.851128 & 15.194167 & 795 & NA & NA & -16 to 25 & 95 & $\mathrm{Vl}: 1$ \\
\hline S20 & wet wall & near Stolpissky v. & Nov-09 & $\mathrm{CZ}$ & 50.851128 & 15.194167 & 795 & 5.4 & 32 & -16 to 25 & 95 & $\mathrm{l}: 4$ \\
\hline S21 & wet wall & near Stolpissky v. & Nov-09 & CZ & 50.857979 & 15.175381 & 651 & NA & NA & -15 to 26 & 85 & VI:34 \\
\hline S22 & spring area & near Prebuz & Jun-09 & $\mathrm{CZ}$ & 50.369118 & 12.629814 & 889 & NA & NA & -19 to 24 & 102 & $\mathrm{VI}: 3$ \\
\hline S23 & mire & Piskovny Cep & Oct-08 & $\mathrm{CZ}$ & 48.923386 & 14.838706 & 462 & 5.8 & NA & -15 to 31 & 74 & VI:2 \\
\hline S24 & mire & Ostrov u Tise & Oct-09 & $\mathrm{CZ}$ & 50.806602 & 14.044199 & 451 & 5.2 & 69 & -15 to 27 & 74 & $\mathrm{~V}: 1 ; \mathrm{VI}: 1$ \\
\hline S25 & mire & Radostin & Dec-07 & $\mathrm{CZ}$ & 49.654999 & 15.888472 & 622 & NA & NA & -18 to 24 & 91 & VI:1 \\
\hline S26 & mire & Radostin & Jan-08 & $\mathrm{CZ}$ & 49.654999 & 15.888472 & 622 & NA & NA & -18 to 24 & 91 & VI:1 \\
\hline S27 & mire & Radostin & Feb-08 & $\mathrm{CZ}$ & 49.654999 & 15.888472 & 622 & NA & NA & -18 to 24 & 91 & V:1; VI:1 \\
\hline S28 & mire & Radostin & Dec-08 & $C Z$ & 49.654999 & 15.888472 & 622 & 3.6 & NA & -18 to 24 & 91 & $\mathrm{Vl}: 1$ \\
\hline S29 & peat bog & Mlynarska slat & Sep-08 & $\mathrm{CZ}$ & 49.022222 & 13.458333 & 995 & 3.9 & 37 & -18 to 24 & 117 & VI:2 \\
\hline $\mathrm{S} 30$ & mire & Swamp & Oct-07 & $\mathrm{CZ}$ & 50.576111 & 14.671297 & 269 & 4.7 & NA & -11 to 31 & 41 & VI:1 \\
\hline S31 & mire & Swamp & Sep-09 & $\mathrm{CZ}$ & 50.575756 & 14.670284 & 267 & NA & NA & -11 to 31 & 41 & VI:6 \\
\hline S32 & pool & near Hostens & Mar-09 & $\mathrm{FR}$ & 44.498576 & -0.639421 & 69 & 5.3 & NA & -5 to 28 & 22 & $\mathrm{~V}: 2$ \\
\hline S33 & pool & near Hostens & Oct-09 & FR & 44.498576 & -0.639421 & NA & NA & NA & -5 to 28 & 22 & $\mathrm{~V}: 1$ \\
\hline
\end{tabular}




\begin{tabular}{|c|c|c|c|c|c|c|c|c|c|c|c|c|}
\hline S34 & lake & Lacanau & May-10 & $\mathrm{FR}$ & 44.963967 & -1.098405 & 13 & 7.1 & 271 & -5 to 28 & 22 & IV:2; V:8 \\
\hline S35 & lake & Lacanau & May-10 & $\mathrm{FR}$ & 44.95908 & -1.099611 & 12 & 7.4 & 323 & -5 to 28 & 22 & III:1; IV:1; V:6 \\
\hline S36 & mire & Marais di Cla & May-10 & $\mathrm{FR}$ & 44.518042 & -0.613 & 71 & 5.0 & 125 & -5 to 28 & 22 & V:2; VI:2 \\
\hline S37 & lake & Le Paludot & May-10 & $\mathrm{FR}$ & 43.85406 & -1.319755 & 24 & 6.1 & 191 & -2 to 25 & 4 & $\mathrm{~V}: 11$ \\
\hline S38 & mire & near Le Paludot & May-10 & $\mathrm{FR}$ & 43.85338 & -1.319978 & 20 & 5.1 & 143 & -2 to 25 & 4 & V:6; VI:4 \\
\hline S41 & lake & Loughhavaul little & Jun-10 & $\mathrm{IE}$ & 51.722373 & -9.57711 & 93 & 7.1 & 92 & -2 to 19 & 9 & I:2; II:4; V:1 \\
\hline S42 & small pool ${ }^{6}$ & near Lough. little & Jun-10 & IE & 51.722373 & -9.57711 & 93 & NA & NA & -2 to 19 & 9 & VI:4 \\
\hline S43 & pool & near Lough Conga & Jul-09 & $\mathrm{IE}$ & 53.446727 & -9.934362 & 22 & 6.7 & 84 & -3 to 19 & 9 & $\mathrm{~V}: 8$ \\
\hline S47 & peat bog & White Lakes & Jun-10 & $\mathrm{IE}$ & 53.43606 & -9.91228 & 26 & 6.8 & 91 & -3 to 19 & 9 & V:10; VI:2 \\
\hline S48 & lake & Maumwee & Jul-09 & $\mathrm{IE}$ & 53.474381 & -9.543631 & 46 & 6.9 & 39 & -3 to 19 & 9 & VI:2 \\
\hline S49 & lake & Maumwee & Jun-10 & IE & 53.474381 & -9.543631 & 46 & 6.8 & 58 & -3 to 19 & 9 & III:1; V:13 \\
\hline S50 & lake & Shannagrena & Jun-10 & $\mathrm{IE}$ & 53.466718 & -9.54649 & 40 & 6.8 & 60 & -3 to 19 & 9 & $\mathrm{~V}: 12$ \\
\hline S51 & lake & Loughaunfree & Jun-10 & $\mathrm{IE}$ & 53.426457 & -9.550713 & 31 & 6.8 & 75 & -3 to 19 & 9 & III:1; V:4 \\
\hline S52 & lake & Upper Lake & Jun-10 & $\mathrm{IE}$ & 51.985394 & -9.565077 & 26 & 6.7 & 42 & -2 to 19 & 9 & $\mathrm{I}: 1 ; \mathrm{V}: 9$ \\
\hline
\end{tabular}




\begin{tabular}{|c|c|c|c|c|c|c|c|c|c|c|c|c|}
\hline S53 & pool & near Ladies View & Jun-10 & $\mathrm{IE}$ & 51.966017 & -9.59701 & 160 & 6.7 & 60 & -3 to 18 & 19 & V:8; VI:4 \\
\hline S54 & spring area & near Lake Fadda & Jun-10 & $\mathrm{IE}$ & 51.927187 & -9.737309 & 300 & 5.9 & 95 & -4 to 17 & 25 & $\mathrm{I}: 5 ; \mathrm{V}: 1 ; \mathrm{VI}: 3$ \\
\hline S55 & pool & Leersumsche veld & Mar-09 & $\mathrm{NL}$ & 52.041485 & 5.438147 & 6 & 4.5 & 21 & -9 to 31 & 42 & VI:2 \\
\hline S56 & lake & PicoE & Nov-09 & PT & 38.4270806 & -28.138508 & 767 & NA & NA & 4 to 19 & 0 & VI:11 \\
\hline S57 & lake & Sete Cidades & Nov-09 & PT & 37.8360639 & -25.758903 & 757 & NA & NA & 5 to 20 & 0 & IV:4; VI:9 \\
\hline S58 & pool & Abisko & Aug-08 & SE & NA & NA & NA & NA & NA & NA & NA & IV:2 \\
\hline S59 & peat bog & Crno jezero & Jun-08 & SI & 46.451275 & 15.4319861 & 1190 & 4.8 & 35 & -15 to 22 & 66 & VI:2 \\
\hline S60 & peat bog & Falski rybnik & Jun-08 & SI & 46.48085 & 15.4155944 & 1250 & 5.5 & 30 & -15 to 22 & 66 & VI:5 \\
\hline S61 & peat bog & Klinske r. & May-10 & SK & 49.428644 & 19.497013 & 612 & 4.5 & NA & -12 to 25 & 69 & $\mathrm{VI}: 4$ \\
\hline S62 & peat bog & Mutnanske r. & May-10 & SK & 49.468536 & 19.289033 & 773 & 4.5 & NA & -13 to 24 & 77 & VI:3 \\
\hline
\end{tabular}

${ }^{1}$ The month and year of sampling.

${ }^{2}$ CZ, Czech Republic; DE, Germany; FR, southwestern France; IE, western Ireland; NL, The Netherlands; PT, Azores Islands; SE, Sweden; SI,

Slovenia; SK, Slovakia.

${ }^{3}$ First numbers, degrees north latitude; second numbers, degrees east (+) or west (-) longitude.

${ }^{4}$ Average daily temperatures (see Table S2 for meteorological stations).

${ }^{5}$ Roman numbers I-VI, unnamed lineages (see text); arabic numbers, number of sequences.

${ }^{6}$ Small pool with Sphagnum, presumably ephemeral.

${ }^{7} \mathrm{NA}$, not available. 
Table S2. Closest meteorological stations to sampling sites.

\begin{tabular}{|c|c|c|c|c|c|}
\hline Meteorological station & \multicolumn{2}{|c|}{$\begin{array}{c}\text { GPS } \\
\text { coordinates }^{1}\end{array}$} & $\begin{array}{l}\text { altitude } \\
\qquad(\mathrm{m})\end{array}$ & records since & samples $^{2}$ \\
\hline IPOCATKY1 & 49.25 & 15.33 & 542 & Dec-2009 & S1, S2, S25-28 \\
\hline IJINRICH1 & 49.14 & 15.02 & 474 & Dec-2009 & $\mathrm{S} 3, \mathrm{~S} 4, \mathrm{~S} 8, \mathrm{~S} 23$ \\
\hline ISACHSEN18 & 51.11 & 13.67 & 225 & Dec-2009 & S5-7 \\
\hline ISACHSEN15 & 50.69 & 12.54 & 294 & Dec-2009 & S22 \\
\hline ILIBEREC1 & 50.83 & 15.02 & 396 & Dec-2009 & S10-21 \\
\hline ISAXONIA2 & 51.10 & 14.39 & 320 & Dec-2009 & S9, S24 \\
\hline IMNICHOV2 & 50.52 & 14.97 & 777 & Jan-2010 & S30, S31 \\
\hline IPLZEU012 & 49.26 & 13.38 & 612 & Jan-2010 & S29 \\
\hline IAULNAYA2 & 46.02 & -0.35 & 62 & Dec-2009 & S32-36 \\
\hline IAQUITAI16 & 43.52 & -1.48 & 45 & Dec-2009 & S37, S38 \\
\hline IKERRYTR2 & 52.31 & -9.63 & 226 & Dec-2009 & S43-51 \\
\hline ICORKWAT2 & 52.01 & -8.34 & 181 & Dec-2009 & S39-42, S52-54 \\
\hline IUTRECHT5 & 52.06 & 5.39 & 7 & Dec-2009 & S55 \\
\hline PONTA DELGADA & 37.74 & -25.70 & 66 & Jan-2010 & S57 \\
\hline HORTA CASTELO BL. & 38.52 & -28.72 & 27 & Jan-2010 & S56 \\
\hline ISLKONJI1 & 46.35 & 15.41 & 342 & Jan-2010 & S59, S60 \\
\hline IPOPRADT1 & 49.17 & 20.28 & 866 & Dec-2009 & S61, S62 \\
\hline
\end{tabular}

${ }^{1}$ First numbers, degrees north latitude; second numbers, degrees east (+) or west (-) longitude.

${ }^{2}$ Sample sites, see Table S1. 